\title{
The Effect of Malathion and Sevin Pesticides Application on Soil and Garden Rocket(Eruca Sativa L.) Growth
}

\author{
Gafar M. O., Yagi M. I., Elhag*, A.Z., Musa S.A. \\ Sudan University of Science and Technology, Khartoum. P.O. Box 71. Khartoum North, Sudan \\ *Corresponding Author: zadhag@yahoo.com
}

Copyright (C) 2013 Horizon Research Publishing All rights reserved.

\begin{abstract}
His study was conducted at College of Agricultural Studies, Sudan University of Science and Technology Farm to evaluate the residual effect of the recommended dose of Malathion (450kg/ha), an organophosphate insecticide, and Sevin(450kg/ha), a carbamate insecticide, on the dry weight and length of garden rocket The result showed that, the recommended dose of Sevin has positively affected both variables; the average length and weight of treated plants. The recommended dose gave significantly higher plant height $(52.1 \mathrm{~cm})$ than the other treatments and higher number of leaves (21.0) and leaf area $\left(11 \mathrm{~cm}^{2}\right.$ and.0 $12.0 \mathrm{~cm}^{2}$, for Malathion and Sevin, respectively).The total nitrogen percentage and extractable phosphorous were significantly affected by both pesticides. The $\mathrm{pH}$ and salinity were not significantly affected.
\end{abstract}

Keywords Sevin, Malathion, Pesticides, Recommended Dose

\section{Introduction}

The world population is rapidly increasing and it needs further research to help increase food production in order to avoid famines, malnutrition and critical shortage in food supply. During the past few decades pesticides were intensively used to increase agricultural production; however the lack of awareness of the risk involved in using pesticides has lead to environmental, pollution and contamination of agricultural resources namely soil and underground water. Previous studies (Zaki, 1978) have shown that the residues of certain pesticides in soil lead to either increase or decrease in nutritional element in soil depending on many interacting factors. Shihu (1980) studied the relationship between the concentration of different pesticides in the soil and their concentration in the plant. The result showed that the ratio fluctuates between the concentration of different pesticides in the soil and their concentration in the plant. The result showed that the ratio fluctuates between $1: 1$ to $1: 6$. Hawrth
(1983) explained that the type of soil has a great impact on the residues detected in plants. He found that the amount of lindane detected in carrot (Daucus carota L.) grown on sand, silt and clay soils was 5.99, 0.156 and 2.41 ppm respectively. Omer (2001) investigated the possibility of contamination of soil with Sevin after 7 years had elapsed and documented that, the soil remained contaminated throughout these years. In fact the results of soil analysis showed that $0.156 \mathrm{ppm}$ of Sevin was detected at the end of the 7 years. The fate of pesticides in soils is greatly determined by soil $\mathrm{pH}$. According to Hagar (2002) most soils have a pH that ranges between 4.5 and 8 . However the adsorption of pesticides is usually greater in soil with high degree of acidity.

Denis (1999) observed that tomato (lycopersion esculentum L.) suffered from dwarfism when treated with an over dose of Sevin. He ascribed this phenomenon to the deformation of roots accompanied by its incapability to absob water and nutritional elements. When the same experiment was conducted using carrot (Daucus carota L.) the vegetative part was greatly increased.

Abedalgwad (2001) performed an experiment to investigate the effect of Sevin on carrots. He found that, the weight of carrot treated with Sevin was significantly increased. This could be related to the fact that, the Sevin acts as growing hormone in certain plants (garden rocket).

Ashraf (2007) stated that, Sevin pesticide reduce the activity of microorganism which lead to the reduction of the absorption of some minerals especially garden rocket plant. He also found that the stability of pesticides in soil depends on the character of the pesticides especially their concentration, solubility and evolution in the air.

Nahla (2011) found that, the pesticides reduce negatively the absorption of some trace element $(\mathrm{Fe}, \mathrm{Zu})$ and affect the viruses found at the root zone of garden rocket plant which reduce their tolerance to some disease. Gafar et. al. $2011^{\mathrm{a}, \mathrm{b}}$ and $\mathrm{c}$ showed the adverse effects of both Malathion and Sevin in both crops and soil.

This study, aims to investigate the effect of Malathion and Sevin on garden rocket growth.

\section{Materiasl and Methods}


A field experiment was conduced at the College Farm $(380 \mathrm{~m})$ above sea level) to study the effect of two pesticides on the garden rocket growth. The treatment Viz, controll, Malathion and Sevin (450 and $650 \mathrm{~kg} /$ each) were used in six plots each. Two concentrations of each (the recommended and the higher dose) were used. Garden rocket was planted on January (2010) on ridge with a spacing of $70 \mathrm{~cm}$. between rows and $10 \mathrm{~cm}$. between plants. Urea and phosphorus fertilizers were used at a rate of $150 \mathrm{~kg} / \mathrm{ha}$ and $120 \mathrm{~kg} / \mathrm{ha}$, respectively. The pesticides were sprayed one month after planting. Plots were separated by sacks to prevent lateral movement of the pesticides. The whole plants were pulled and then washed for different measurement. Soil samples were taken before and after planting from $30 \mathrm{~cm}$. depth for all treatment. Measurements taken were height $(\mathrm{cm})$, fresh and dry weight $(\mathrm{gm})$, leaf area $(\mathrm{cm} 2), \mathrm{pH}$, total nitrogen\%, Ece $(\mathrm{ds} / \mathrm{m})$, ), leaf number. The data were subjected to statistical analysis (Gomez and Gomez, 1984) using the soft ware package MSTATC and LSD at $\mathrm{P} \leq 0.05$ was used for the separation of means.

\section{Results \& Discussion}

The results (Table1) revealed that the plant height at the recommended dose of Malathion was taller $(52.1 \mathrm{~cm})$ than the others and the higher dose it was significantly shorter than the others $(36.2 \mathrm{~cm})$. It also showed that the number of leaves was significantly affected (reduced by more than $50 \%$ ) at the higher dose. Number of leaves were significantly higher at the recommended dose (21.0). Leaf area at the recommended dose $\left(11.5 \mathrm{~cm}^{2}\right)$ was higher than the control but significantly higher than the higher dose. The root length was positively affected by the recommended dose (Longer, $21.0 \mathrm{~cm}$, than the control, $17.0 \mathrm{~cm}$ ) but it was significantly reduced (13.0) at the higher dose. The same was observed on the shoot fresh and dry weight which were significantly reduced (almost $50 \%$ or more compared to control)

The same trend was observed for the Sevin treatments (Table2), where, the recommended dose had also positive effects on growth parameters, which were reduced significantly by the higher dose. The plant height of the recommended Sevin dose $(51.5 \mathrm{~cm})$ was not significantly different from the control but significantly higher (Table 2) than both lower and higher doses. Number of leavers of the control (16) was not significantly higher than recommended (21.0) but significantly higher than lower. Leaf area (12.05 $\mathrm{cm} 2$ ) of the recommended dose (Tble 2) was not significantly different from the control or the lower Sevin dose but significantly higher than the leaf area of the higher dose. Table 2 also showed that the effect of the doses on root length was not significant but the control $(16.8 \mathrm{~cm})$ had the highest length while the higher dose $(4.50 \mathrm{~cm})$ had the lowest root length.

In general the recommended dose of Malathion gave better results than the recommended dose of Sevin. These results were on line with Gafar et al., 2011(a) and Gafar et al., 2011(b) findings. Also Abedalgwad (2001) found that the weight of carrot treated with Sevin was significantly increased. This could be related to the fact that, the Sevin acts as growing hormone in certain plants (garden rocket)

The effect of Malathion and Sevin addition to the soil was variable (Table 3). The total nitrogen percentage and extractable phosphorous were higher in the soil before planting and reduced with the pesticides addition. The $\mathrm{pH}$ was not affected that much by the addition of different doses but it was higher for Malathion than for Sevin. The salinity of the soil (Table 3) was less before planting $(1.7 \mathrm{dS} / \mathrm{m})$ and increased for the higher doses $(2.57,2.94)$ and the recommended doses $(2.55,2.15 \mathrm{dS} / \mathrm{m})$ for Malathion and Sevin, respectively. Similar results were obtained by Ashraf (2007) who stated that Sevin pesticide reduce the activity of microorganism which lead to the reduction of the absorption of some minerals, especially, in garden rocket plant. He also found that the stability of pesticides in soil depends on the character of the pesticides especially their concentration, solubility and evolution in the air.

Nahla (2011) found that, the pesticides reduce the absorption of some trace element $(\mathrm{Fe}, \mathrm{Zu})$ and affect the viruses found at the root zone of garden rocket plant which reduce their tolerance to some diseases. Moreover Gafar et. al. $2011^{\mathrm{a}, \mathrm{b} \text { and } \mathrm{c}}$ reported adverse effects of both Malathion and Sevin in both crops and soil.

Table 1. Effect of Malathion on growth of garden rocket

\begin{tabular}{|c|c|c|c|c|c|c|}
\hline Treatment & $\begin{array}{c}\text { Plant Height } \\
(\mathrm{cm})\end{array}$ & Number of leaves & $\begin{array}{c}\text { Leaf area } \\
\left(\mathrm{cm}^{2}\right)\end{array}$ & $\begin{array}{c}\text { Root length } \\
(\mathrm{cm})\end{array}$ & $\begin{array}{c}\text { Fresh weight } \\
(\mathrm{g})\end{array}$ & Dry weight (g) \\
\hline Control & 46.1 & 16 & 8.7 & 17.0 & 24.0 & 1.1 \\
\hline $\begin{array}{c}\text { Recommended } \\
\text { dose (450kg/ha) }\end{array}$ & 52.1 & 21.0 & 11.5 & 21.0 & 28.0 & 1.6 \\
\hline $\begin{array}{c}\text { Higher than recommended } \\
\text { dose (650kg/ha) }\end{array}$ & 36.2 & 10.0 & 5.9 & 13.0 & 14.0 & 0.54 \\
\hline LSD (0.05) & 10.3 & 5.2 & 4.1 & 5.6 & 6.1 & 0.52 \\
\hline
\end{tabular}


Table 2. Effect of Sevin doses on Growth of garden rocket

\begin{tabular}{|c|c|c|c|c|c|c|}
\hline Treatment & $\begin{array}{c}\text { Plant Height } \\
(\mathrm{cm})\end{array}$ & $\begin{array}{c}\text { Number of } \\
\text { leaves }\end{array}$ & $\begin{array}{c}\text { Leaf area } \\
\left(\mathrm{cm}^{2}\right)\end{array}$ & $\begin{array}{c}\text { Root length } \\
(\mathrm{cm})\end{array}$ & $\begin{array}{c}\text { Fresh weight } \\
(\mathrm{g})\end{array}$ & Dry weight $(\mathrm{g})$ \\
\hline Control & 46.5 & 16.0 & 9.2 & 16.8 & 28.4 & .1 .1 \\
\hline $\begin{array}{c}\text { Recommended } \\
\text { dose }(1.9 \mathrm{~kg} / \mathrm{he})\end{array}$ & 51.5 & 21.0 & 12.8 & 21.6 & 33.6 & 1.8 \\
\hline $\begin{array}{c}\text { Higher than recommended } \\
\text { dose }(650 \mathrm{~kg} / \mathrm{he})\end{array}$ & 29.2 & 8.0 & 5.80 & 10.6 & 15.5 & 0.6 \\
\hline LSD $(0.05)$ & 7.8 & 6.5 & 4.5 & 6.2 & 10.8 & 0.5 \\
\hline
\end{tabular}

Table 3. Soil analysis before and after addition of Malathion \& Sevin.

\begin{tabular}{|c|c|c|c|c|}
\hline Parameter & Total Nitrogen percentage & $\begin{array}{c}\text { Extractable } \\
\text { Phosphorus } \\
\text { Ppm }\end{array}$ & pH paste & E.C. ds/m \\
\hline Soil before planting & 0.09 & 6.00 & 8.30 & 1.70 \\
\hline Higher Malathion dose & 0.03 & 3.00 & 8.70 & 2.57 \\
\hline Recommended Metalhion dose & 0.06 & 4.90 & 8.40 & 2.55 \\
\hline Higher Sevin dose & 0.01 & 4.00 & 8.50 & 2.15 \\
\hline Recommended Sevin dose & 0.08 & 5.00 & 0.53 & 0.45 \\
\hline Lsd (5\%) & 0.04 & 2.00 & & 2.94 \\
\hline
\end{tabular}

\section{Conclusion}

It is clear that the use of higher doses of insecticides, especially, Malathion and Sevin have adverse effects on both plant growth and environment, whereas that of the recommended dose might have synergistic effects on growth and mineral absorption compared to control, in addition to pest control. So in case of heavy infestation the use of pesticides might be un inevitable for vegetables production. The recommended dose of both Malathion and Sevin can be applied safely when a few basic rules are followed and common sense is used.

\section{REFERENCES}

[1] Abdlegwad, A. A. (2001). Contamination of Agricultural Soil Cairo University, 2nd edition. Dar Elthagfa press.

[2] Abdlegwad A. A. (2001). Performed an experiment to investigate the effect of Sevin on carrot. Cairo University. Dar Elthgafa press. Cairo, Egypt.

[3] Abdel - Hamed, Z. H. (1995). Pointed out that pesticides residues might affect the presence of some minerals especially trace elements. Ain Shamish University, Arabic distribution and printing House. Baruit, Lebnan.

[4] Ashraf, E, A. (2007). The stability of pesticides in soil depend on the character of the pesticides especially then concentration, solubility and evolution in the air. Agricultural Research Journal, Wad Madani - Sudan.

[5] Ashraf, E. A. (2010). Sevin pesticides reduce the activity of micro organism which lead to the reduction of the absorption of some minerals by portulaca. . Agricultural Research Journal, Wad Madani - Sudan.

[6] Dennis, C. A. (1999). Reported that Sevin acted as a nitrogenous fertilizer when sprayed on leaves of lattuce and lead to noticeable increase on the length and density of plant after two weeks of treatment. University of Alexandria Egyptian library for printing and distribution. Egypt.

[7] Gafar, M. O. and Dagsh, Y. M. (a) (2011). The resielual effect of Sevin on the vegetative growth of potato. American journal of experimental Agriculture 1(4). 226 - 230, 2011.

[8] Gafar. M. O. ad Dagash Y. M. b (2011). The residual effect of Malathion on the growth of potato. American Journal of experimental agriculture (4) 226-230, 2011.

[9] Gafar,. M. O. and Dagash Y. M. (a) (2011). The effect of Malathion pesticides on garlic growth. Research Journal of Agriculture and Biological Science, 7 (3): 332 - 334, 2011. ISSN $1816-1581$.

[10] Gafar, M. O. and Dagash (b) (2011). The effect Sevin pesticdes on garlic growth. Research Journal of Agricultural and Biological Sciences 7 (3): 332 - 334, 2011.

[11] Gafar, M. O. et. al. c (2012). The effect of Sevin and Malathion pesticides on radish growth. International Research Journal of Agriculture Science and soil science (ISSN) 2251 - volume 2(2) pp $058-042-247$.

[12] Gomez, K. A. and Gomez, A. A. (1984). Statistical Procedures for Agricultural Research. John Wiley and Sons, New York.,

[13] Hagar M. G. (2002). The fate of pesticides in soil. A paper presented at a workshop at Arab corporation for development. Khartoum, Sudan.

[14] Hawrth (1983). Salmonella mutagen city test results for 250 
chemicals environmental mutagen.

[15] Nahla (2011). Stated that, pesticides residues negatively affect the viroses found at the root zone of portulaca which reduce their tolerance of some diseases. Https// docs. Google. $\mathrm{com} /$ reviwer. Vandq.

[16] Omer I. E. (2001). Pesticides residues in Elfashin Agriculture area, Workshop at Alfashir city. Western Darfor state, Sudan.
[17] Shier et. al (1980). Mutagen city and DNA. Damegening activity for several pesticides. Mutagen Research.

[18] Younis, 1. (1978). Explained the effect of chemical pesticides on the environment. Alexandria University. Dar Almaarief press.

[19] Z-akki, M. M. (1978). Explained the effect of pesticides on the environment. Einshamis University 2nd edition. Elder Alarabic press. 